\title{
Body image in different periods of adolescence
}

\author{
Imagem corporal em diferentes períodos da adolescência \\ Imagen corporal en distintos periodos de la adolescencia
}

Valter Paulo N. Miranda', Maria Aparecida Conti², Pedro Henrique B. de Carvalho ${ }^{3}$, Ronaldo Rocha Bastos ${ }^{3}$, Maria Elisa C. Ferreira ${ }^{3}$

\section{ABSTRACT}

Objective: To analyze body image in different periods of adolescence.

Methods: This cross-sectional study enrolled students aged ten to 19 years old of public schools in small districts of Minas Gerais, Southeast Brazil. The Body Shape Questionnaire (BSQ), the Body Dissatisfaction Assessment Scale for Teenagers and the Silhouette Scale for Teenagers (SST) were used. Adolescence phases were classified according to the subjects' ages. Weight and height were measured in order to calculate the body mass index and the nutritional status. Results were analyzed by logistic regression.

Results: The study emolled 531 teenagers (318 females). The average age was $15.6 \pm 2.2$ years and $84.6 \%$ were eutrophic. The prevalence of body dissatisfaction varied from $28.9 \%$ (BSQ) to $78.9 \%$ (SST). Overweight adolescents presented greater dissatisfaction (BSQ: OR 3.66, $p<0.001$; SST: OR 4.108, $p<0.001)$. Dissatisfaction also occurred for females and those at the early adolescence $(p<0.05)$.

Conclusions: A low prevalence of dissatisfaction with the body image was observed among adolescents in small towns of Minas Gerais; however, most of them wished a different silhouette than the current one. The results showed that younger adolescents had higher dissatisfaction than their peers, as well as female and overweighed adolescents.

Key-words: body image; adolescent; sex; nutritional status; adolescent health.
RESUMO

Objetivo: Investigar a imagem corporal em diferentes períodos da adolescência.

Métodos: Estudo transversal com estudantes de dez a 19 anos de escolas da rede pública de municípios de pequeno porte do interior da Zona da Mata Mineira. Aplicaram-se o Body Shape Questionnaire (BSQ), a Escala de Evaluación de Insatisfación Corporal para Adolescentes e a Escala de Silhueta para Adolescentes (ESA). Classificou-se o período da adolescência por meio da idade. A massa corporal e a estatura foram mensuradas para o cálculo do índice de massa corpórea e do estado nutricional. Os resultados foram avaliados por regressão logística.

Resultados: Participaram 531 adolescentes (318 meninas).

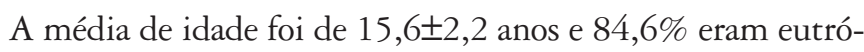
ficos. A prevalência de insatisfação corporal variou de $28,9 \%$ (BSQ) a 78,9\% (ESA). Indivíduos com excesso de peso apresentaram maior chance de insatisfação (BSQ: OR 3,66, $p<0,001$; ESA: OR 4,108, $p<0,001)$. O mesmo ocorreu para meninas e indivíduos no período inicial da adolescência $(p<0,05)$.

Conclusões: A prevalência de insatisfação com a imagem corporal foi baixa entre os adolescentes das cidades pequenas de Minas Gerais, porém a maioria desejava uma silhueta diferente da atual. Os resultados mostraram maior insatisfação entre os participantes no período inicial da adolescência, assim como nos do sexo feminino e naqueles com excesso de peso.

Palavras-chave: imagem corporal; adolescente; sexo; estado nutricional; saúde do adolescente.
Instituição: Laboratório de Estudo do Corpo da Faculdade de Educação Física e Desportos da Universidade Federal de Juiz de Fora (UFJF), Juiz de Fora, MG, Brasil

'Universidade Federal de Viçosa (UFV), Viçosa, MG, Brasil

${ }^{2}$ Faculdade de Medicina da Universidade de São Paulo (USP), São Paulo, SP, Brasil

${ }^{3} \mathrm{UFJF}$, Juiz de Fora, MG, Brasil
Endereço para correspondência:

Valter Paulo N. Miranda

Avenida Deputado Último de Carvalho, s/n - Centro

CEP 36165-000 - Tabuleiro/MG

E-mail: vpnmiranda@yahoo.com.br

Conflito de interesse: nada a declarar

Recebido em: 1/8/2013

Aprovado em: 6/10/2013 


\section{RESUMEN}

Objetivo: Investigar la imagen corporal en distintos periodos de la adolescencia.

Métodos: Estudio transversal con estudiantes de diez a 19 años de escuelas de la red pública de municipios de pequeño porte del interior de la Zona de Bosque de Minas Gerais (Brasil). Se aplicaron el Body Shape Questionnaire (BSQ), la Escala de Evaluación de Insatisfacción Corporal para Adolescentes y la Escala de Silueta para Adolescentes (ESA). Se clasificó el periodo de la adolescencia por la edad. La masa corporal y la estatura fueron medidas para el cálculo del índice de masa corporal y del estado nutricional. Se realizaron análisis descriptivo, inferencias y regresión.

Resultados: Participaron 531 adolescentes (318 mucha-

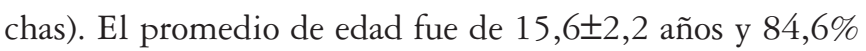
eran eutróficos. La prevalencia de insatisfacción corporal varió del 28,9\% (BSQ) al 78,9\% (ESA). Individuos con exceso de peso presentaron mayor posibilidad de insatisfacción (BSQ: OR 3,66, $p<0,001$; ESA: OR 4,108, $p<0,001)$. Lo mismo pasó con muchachas e individuos en el periodo inicial de la adolescencia $(p<0,05)$.

Conclusiones: La prevalencia de insatisfacción con la imagen corporal fue baja entre los adolescentes de las ciudades pequeñas de Minas Gerais, pero la mayoría deseaba una silueta distinta de la actual. Los resultados mostraron mayor insatisfacción entre los participantes en el periodo inicial de la adolescencia, así como en los del sexo femenino y en aquellos con exceso de peso.

Palabras clave: imagen corporal; adolescente; sexo; estado nutricional; salud del adolescente.

\section{Introduction}

Adolescence is a developmental stage of a human being in which the process of biopsychosocial maturation occurs intensively ${ }^{(1)}$. The World Health Organization (WHO) ${ }^{(2)}$ adopts the chronological criteria, defining adolescence as the life span from 10 to 19 years, 11 months and 29 days. It can be divided into three periods: early (10-13 years), middle (14-16 years) and late (17-21 years) adolescence ${ }^{(3)}$. Childhood and adolescence are periods of life marked by great vulnerability, because they represent stages in which the human being is growing and developing, both physically and intellectually ${ }^{(4)}$.
During the periods of adolescence, morphological changes occur in both sexes ${ }^{(5)}$. Such sudden changes in physical appearance may influence adolescents' assessment of their body image ${ }^{(6)}$, which is a multidimensional construct involving the accuracy of the perception that the person has regarding body shape and size, along with the feelings this representation may cause ${ }^{(4)}$. The concern with weight is a major factor associated with increased body dissatisfaction $^{(6,7)}$. It is observed that the physical form considered attractive may not be achieved successfully and thus some actions are taken to achieve a possible satisfaction. However, these attitudes are often harmful to health, such as unhealthy eating behaviors, inappropriate practices of weight control, overuse of diuretics and laxatives, vomiting, and strenuous physical activity ${ }^{(8)}$. To evaluate this negative feeling in relation to body image, the researcher may use culturally adapted instruments for the adolescent population. Questionnaires and self-assessment scales are best suited to evaluate the components of body image, both in epidemiological studies and in clinical studies ${ }^{(9)}$.

Some studies ${ }^{(6-10)}$ were conducted among Brazilian adolescents, but there are few national studies investigating body image in different periods of adolescence ${ }^{(11)}$. Accordingly, the aim of this study was to assess body image of adolescents living in small municipalities in the state of Minas Gerais, in the early, middle, and late periods of adolescence, according to sex and nutritional status.

\section{Method}

This is a descriptive cross-sectional and observational study, and the population consisted of adolescents ${ }^{(2)}$ of both sexes, regularly enrolled at public schools in small municipalities ${ }^{(12)}$ in the countryside of Zona da Mata Mineira. We found nine municipalities with a population lower than five thousand inhabitants in the above region ${ }^{(13)}$ and, subsequently, the researcher visited the schools to get the consent from the direction to conduct the research and to collect information on the number of adolescents, ages, and sex.

We used a cluster sample, from a universe of nine schools (clusters) and a finite population of 1,015 students. To calculate the sample size, significance was established at $5 \%$, an absolute accuracy of 5.5 percentage points in the variable reference response - the score of the Body Shape Questionnaire (BSQ) $)^{(14)}$ - and the maximum variability observed in the literature as the expected standard deviation, 
corresponding to the female sex (standard deviation: 34.3 points $)^{(14)}$. Thus, we came to the minimum sample size of 129 , already with the finite-population correction.

To allow independent interferences for the three periods of adolescence, considering each one as stratum, the initial sample size was multiplied by three (for the periods of adolescence), which generated a minimum sample size of 387 students. The following municipalities were selected by simple random sampling (SRS): Goianá ( $\mathrm{n}=191)$, Tabuleiro $(n=207)$, Belmiro Braga $(n=130)$, and Pequeri $(n=124)$. The late number of analyzed students was 651 .

Among the 651 evaluated participants, 120 individuals were excluded: eight lived in another municipality, two made use of controlled medications, 27 claimed not having permission from the parents, $43 \mathrm{did}$ not hand over the term of consent signed by parents, and 40 attended only one day of data collection. At the end, the research involved 531 students, a greater number than the recommended by the sample calculation.

The instruments selected for body image assessment were those with transcultural adaption for Brazilian adolescents: The Body Shape Questionnaire (BSQ) ${ }^{(14)}$, the Escala de Evaluación de Insatisfación Corporal para Adolescentes (EEICA) ${ }^{(15)}$, and the Silhouette Scale for Adolescents (SSA) ${ }^{(16)}$.

The $\mathrm{BSQ}^{(14)}$ is a questionnaire consisting of 34 questions in a Likert-like self-report scale, with six response options (1 - never to 6 - always), and four levels of dissatisfaction with physical appearance, following the model proposed by Cordás and Castilho ${ }^{(17)}$, according to the scores: free of body dissatisfaction - below 80 points; mild dissatisfaction - from 80-110 points; moderate dissatisfaction - 110 to 140 points; and severe dissatisfaction - equal to or above 140 points.

The EEICA ${ }^{(15)}$ provides information about the frequency of behaviors related to care and bodily perception and the social and family influences on body dissatisfaction. The scale consists of 32 self-report questions in a Likert-like scale, with six response options ( 1 - never to 6 -always). The score ranges from zero to 96 points and, the higher the score, the greater the body dissatisfaction.

The SSA ${ }^{(16)}$ consists of nine figures of silhouettes for each sex. The categorization of the level of satisfaction (LS) was performed by the difference in the choice between the ideal silhouette (IS) and the real silhouette (RS). Adolescents who presented a difference equal or below zero $(\mathrm{LS}=0)$ were classified as satisfied, and those with a difference different than zero (LS $\neq 0$ ) were classified as dissatisfied.
Age and sex were self-reported and the classification of body mass index (BMI) [weight $(\mathrm{kg}) /$ height $(\mathrm{m})^{2}$ ] was used as the primary assessment of nutritional status. The categorization of the adolescence period was performed as proposed by the $\mathrm{WHO}^{(3)}$ : early period (Early) - 10 to 13 years; middle period (MP) - 14 to16 years; and late period (LP) -17 to 21 years. Anthropometric data were collected with adolescents wearing a physical education uniform, barefoot, and weighed on an electronic platform scale $\left(\mathrm{G}-\mathrm{Tech}^{\circledR}\right)$, with a capacity for $150 \mathrm{~kg}$ and $100 \mathrm{~g}$-graduation. Placing the teenager in the middle of the platform, two measures were assessed ${ }^{(18)}$. Subsequently, each student went to the wall-mounted stadiometer, in the upright position, leaning against the back wall, looking forward, feet together and heels touching. Two measures for height were assessed, and we considered the mean of this value ${ }^{(18)}$. Nutritional status was categorized according to the percentile values for age and gender ${ }^{(19)}$ : low BMI - percentiles below 3; eutrophic between 3 and 85; overweight - between 85 and 97; and obesity - percentile above 97.

A descriptive analysis was performed using frequency, mean values, and standard deviations. For the analysis of body dissatisfaction, adolescence was categorized by periods, creating three strata according to sex. For males: MEP (male early period), MMP (male middle period) and MLP (male late period); for females: FEP (female early period), FMP (female middle period) and FLP (female late period).

As the numerical variables were not normal by the Kolmogorov-Smirnov test, we chose the application of non-parametric tests. The chi-square, in the case of ordinal factors, and the Fisher exact test for the nominal factor, were applied to examine the associations of adolescence, sex, and nutritional status as well as the frequency of subjects classified as satisfied and dissatisfied by the SSA and the BSQ.

The variation in scores of dissatisfaction with body image between different periods of adolescence and between groups of nutritional status was evaluated by the Kruskal-Wallis test and the post hoc Bonferroni's test. To compare the mean scores of the instruments between both sexes and groups related to the adolescence period, we applied the MannWhitney's U test.

Then, a model of binary logistic regression was adjusted to determine which of the independent variables had a significant association (risk or protection) with the SSA or the BSQ classifications of body dissatisfaction, according to the interpretation of values for Odds Ratio (OR) and significance $(p)$. 
These analyzes were based on the variables male sex, Early Period and low BMI, and eutrophic. To meet the requirement of the dichotomy of the response variable, the BSQ was reorganized into two categories: satisfied (classified as free of body dissatisfaction) and dissatisfied (with some level of dissatisfaction: mild, moderate, or severe). The same was used for the nutritional status variable, which had the four categories grouped into two: underweight and eutrophic; overweight and obesity. The statistical software Statistical Package for the Social Sciences (SPSS), version 17.0, was used with a level of significance of $5 \%$ for the respective analyses.

This study was approved by the Research Ethics Committee of Universidade Federal de Juiz de Fora (protocol n. 1612.302.2008; opinion 416/2008) and its implementation is in accordance with Resolution n. 196/96 from the Brazilian National Health Council.

\section{Results}

The mean age of the adolescents was of $15.6 \pm 2.2$ years; $158(28.7 \%)$ were in the EP, $290(52.6 \%)$ in the MP and $103(18.7 \%)$ in the LP. Among all participants, $233(42.3 \%)$ were male and $318(57.7 \%)$ female. The results of weight, height, BMI, and nutritional status classification for the period of adolescence are available in Table 1.

In the assessment by the BSQ, $392(71.1 \%)$ subjects were satisfied with their body image, while 159 (28.9\%) were dissatisfied - $100(18.1 \%)$ with mild dissatisfaction, $41(7.4 \%)$

Table 1 - Descriptive analysis of anthropometric variables for the periods of adolescence. Juiz de Fora - MG, 2010

\begin{tabular}{lcccc}
\hline \multirow{2}{*}{ Variables } & \multicolumn{3}{c}{ Period of adolescence } & \multirow{2}{*}{ Total } \\
\cline { 2 - 4 } & EP & MP & LP & \\
\hline Weight $(\mathrm{kg})^{*}$ & $51.7 \pm 13.0$ & $59.5 \pm 12.3$ & $64.1 \pm 14.0$ & $58.14 \pm 13.6$ \\
${\text { Height }(\mathrm{m})^{*}}_{\mathrm{BMI}^{*}}^{1.50 \pm 0.90}$ & $1.65 \pm 0.09$ & $1.67 \pm 0.10$ & $1.63 \pm 0.10$ \\
$\mathrm{EN}-\mathrm{n}(\%)^{* *}$ & $20.7 \pm 4.1$ & $21.6 \pm 3.6$ & $22.9 \pm 3.9$ & $21.13 \pm 3.8$ \\
Low BMl & & & & \\
Eutrophic & $4(2.5)$ & $7(2.4)$ & $2(1.9)$ & $13(2.4)$ \\
Oberweight & $133(84.2)$ & $245(84.5)$ & $88(85.4)$ & $466(84.6)$ \\
Obesity & $18(11.4)$ & $31(10.7)$ & $11(10.7)$ & $60(10.9)$ \\
\hline
\end{tabular}

EP: early period; MP: middle period; LP: late period; BMI: body mass index; NS: nutritional status; n: absolute frequency; \%: relative frequency. ${ }^{*}$ Data as mean and standard deviation. with significant variation among adolescents in the LP $(p<0.05)$; ${ }^{* *}$ significant higher frequency of normal adolescents $(p<0.05)$

Table 2 - Dissatisfaction in relation to the period of adolescence, sex and nutritional state, Juiz de Fora - MG, 2010

\begin{tabular}{|c|c|c|c|c|c|c|c|}
\hline & \multirow{2}{*}{$\begin{array}{c}\text { BSQ } \\
\text { (mean } \pm \text { SD) }\end{array}$} & \multirow{2}{*}{$p$-value } & \multirow{2}{*}{$\begin{array}{c}\text { EEICA } \\
(\text { mean } \pm \text { SD) }\end{array}$} & \multirow{2}{*}{$p$-value } & \multicolumn{2}{|c|}{ SSA n(\%) } & \multirow{2}{*}{$p$-value } \\
\hline & & & & & Satisfied & Dissatisfied & \\
\hline \multicolumn{8}{|c|}{ Adolescence period } \\
\hline Early & $71.6 \pm 31.2$ & 0.083 & $21.2 \pm 12.0$ & $<0.001$ & $14(8.9)$ & $144(91.1)$ & $<0.001$ \\
\hline Middle & $67.2 \pm 30.0$ & & $17.7 \pm 11.6$ & & $72(24.8)$ & $218(75.2)$ & \\
\hline Late & $62.7 \pm 27.8$ & & $18.2 \pm 10.9$ & & $30(29.1)$ & $73(70.9)$ & \\
\hline \multicolumn{8}{|l|}{ Sex } \\
\hline Male & $58.44 \pm 25.9$ & $<0.001$ & $16.43 \pm 8.9$ & 0.003 & $59(25.3)$ & $174(74.7)$ & 0.023 \\
\hline Female & $74.37 \pm 31.1$ & & $20.62 \pm 13.1$ & & $57(17.9)$ & $261(82.1)$ & \\
\hline \multicolumn{8}{|l|}{ NS } \\
\hline Low BMI & $62.9 \pm 14.0^{\mathrm{a}}$ & $<0.001$ & $18.2 \pm 12.4$ & & $1(7.7)$ & $12(92.3)$ & 0.008 \\
\hline Eutrophic & $64.8 \pm 28.5^{\mathrm{a}}$ & & $17.7 \pm 10.8$ & & $110(23.6)$ & $356(76.4)$ & \\
\hline Overweight & $84.3 \pm 32.0^{\mathrm{a}, \mathrm{b}}$ & & $24.3 \pm 12.8$ & & $4(6.7)$ & $56(93.3)$ & \\
\hline Obesity & $99.2 \pm 46.4^{b}$ & & $33.2 \pm 19.9$ & & $1(8.3)$ & $11(91.7)$ & \\
\hline Total & $67.6 \pm 30.0$ & & $18.8 \pm 11.6$ & & $116(21.1)$ & 435 (78.9) & \\
\hline
\end{tabular}

EP: early period; MP: middle period; LP: late period; M: male; F: female; BMI: body mass index; NS: nutritional status; BSQ: Body Shape Questionnaire; EEICA: Escala de Evaluación de Insatisfacción Corporal para Adolescentes; SSA: Silhouette Scale for Adolescents; SD: standard

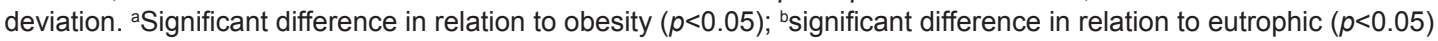


with moderate dissatisfaction, and $18(3.3 \%)$ with severe body dissatisfaction. The evaluation of the SSA showed that $116(21.1 \%)$ adolescents were satisfied with their body image $(\mathrm{SSA}=0)$, while $435(78.9 \%)$ were dissatisfied $(\mathrm{SSA} \neq 0)$.

The mean score of body dissatisfaction of the BSQ, EEICA, and the SSA are shown in Table 2. It was found that individuals in the MP were more dissatisfied in comparison to adolescents in the MP and the LP (EEICA and SSA $p<0.001)$. There were also differences between the sexes, with greater dissatisfaction in female than in male adolescents in the evaluation of all instruments $(p<0.05)$. Overweight and obese adolescents were also more dissatisfied in comparison to those with low BMI (BSQ $-p<0.001$ ).

Specifically girls in the EP of adolescence had the highest prevalence of body image dissatisfaction among the three observed periods (EEICA $-p=0.002$; SSA $-p=0.005$ ) (Table 3). According to the classification of BSQ, female adolescents in the LP were more often classified as with free and low dissatisfaction in comparison to those in the EP. Regarding male adolescents, the significance of variation in body dissatisfaction by the analysis of the BSQ presented a value of $p=0.05$, and those in the EP were more dissatisfied than those in MP and LP (SSA $-p=0.006$ ).

Of the 435 adolescents classified as dissatisfied by the SSA, $60.8 \%$ wanted a smaller silhouette than the current and $39.2 \%$, a greater one. Finally, it was observed that some adolescents classified as eutrophic also expressed body dissatisfaction (BSQ - 25\%; SSA - 76\%), especially girls, and $33 \%$ of eutrophic adolescents revealed dissatisfaction with their body image (BSQ) (Table 2).

The binary logistic regression model, from the OR risk estimator, confirmed that female adolescents, in the EP, with overweight or obesity had a significant association with body dissatisfaction (Table 4). The model according to the SSA showed that females were more dissatisfied than male adolescents (OR 1.49; $p=0.063)$. Regarding adolescents in

Table 3 - Value of body dissatisfaction according to the period of adolescence and according to sex. Juiz de Fora - MG, 2010

\begin{tabular}{lcccccccc}
\hline Variables & ME & MM & ML & $\boldsymbol{p}$-value & FE & FM & FL & $p$-value \\
\hline BSQ (mean \pm SD) & $64.2 \pm 29.1$ & $57.7 \pm 23.7$ & $52.7 \pm 26.3$ & 0.050 & $76.42 \pm 31.7$ & $74.4 \pm 32.2$ & $70.83 \pm 26.4$ & 0.723 \\
EEICA (mean \pm SD) & $17.35 \pm 8.0$ & $15.42 \pm 7.6$ & $17.9 \pm 12.4$ & 0.194 & $23.73 \pm 13.4$ & $19.5 \pm 13.6$ & $18.56 \pm 9.7$ & 0.002 \\
BSQ Classification [n (\%)] & & & & & & & & \\
$\quad$ Free & $44(71)$ & $106(84.8)$ & $43(93.5)$ & 0.008 & $56(58.3)$ & $104(63.6)$ & $39(68.4)$ & 0.704 \\
Light & $11(17)$ & $12(9.6)$ & $1(2.2)$ & 0.023 & $24(25.0)$ & $38(23.0)$ & $14(24.6)$ & 0.140 \\
$\quad$ Moderate & $6(9.7)$ & $6(4.8)$ & - & - & $12(12.5)$ & $14(8.5)$ & $3(5.3)$ & - \\
$\quad$ Severe & $1(1.6)$ & $1(0.8)$ & $2(4.3)$ & - & $4(4.2)$ & $9(5.5)$ & $1(1.8)$ & - \\
SSA [n (\%)] & & & & & & & & \\
$\quad$ Satisfied & $7(11.3)$ & $35(28.0)$ & $17(37.0)$ & 0.006 & $7(7.3)$ & $37(22.4)$ & $13(22.8)$ & 0.005 \\
$\quad$ Dissatisfied & $55(88.7)$ & $90(72.0)$ & $69(63.0)$ & - & $84(92.7)$ & $128(77.6)$ & $44(37.2)$ & - \\
\hline
\end{tabular}

ME: male early period; MM: male middle period; ML: male late period; FE: female early period; FM: Female middle period; FL: Female late period; BSQ: Body Shape Questionnaire; EEICA: Escala de Evaluación de Insatisfacción Corporal para Adolescentes; SSA: Silhouette Scale for Adolescents

Table 4 - Binary logistic regression model between the classification of body image according to the Silhouette Scale for Adolescents and the Body Shape Questionnaire regarding the period of adolescence, sex, and nutritional status

\begin{tabular}{lcccccccccccc}
\hline $\begin{array}{l}\text { Explanatory } \\
\text { variables }\end{array}$ & \multicolumn{3}{c}{$\beta$} & \multicolumn{4}{c}{ SE } & \multicolumn{4}{c}{ Wald Statistic } & \multicolumn{2}{c}{ DF } & \multicolumn{2}{c}{$\boldsymbol{p}$-value } & \multicolumn{2}{c}{ OR } \\
\cline { 2 - 12 } & SSA & BSQ & SSA & BSQ & SSA & BSQ & SSA & BSQ & SSA & BSQ & SSA & BSQ \\
\hline Girls & 0.402 & 1.062 & 0.216 & 0.215 & 3.452 & 24.367 & 1 & 1 & 0.063 & $<0.001$ & 1.494 & 2.893 \\
EP & & & & & 18.597 & 7.812 & 2 & 2 & $<0.001$ & 0.020 & & \\
MP & -1.229 & -0.422 & 0.314 & 0.222 & 15.366 & 3.611 & 1 & 1 & $<0.001$ & $<0.001$ & 0.293 & 0.656 \\
LP & -1.446 & -0.827 & 0.358 & 0.309 & 16.343 & 7.177 & 1 & 1 & $<0.001$ & $<0.001$ & 0.235 & 0.437 \\
$\begin{array}{l}\text { Overweight/ } \\
\text { obesity }\end{array}$ & 1.413 & 1.298 & 0.481 & 0.271 & 8.642 & 22.954 & 1 & 1 & $<0.001$ & $<0.001$ & 4.108 & 3.66
\end{tabular}

SE: standard error; DF: degree of freedom; OR: Odds Ratio; SSA: Silhouette Scale for Adolescents; BSQ: Body Shape Questionnaire; EP: early period; MP: middle period; LP: late period 
the MP and LP they presented, respectively, 70\% (OR 0.29; $p<0.001$ ) and $76 \%$ (OR $0.23 ; p<0.001$ ) less change of being dissatisfied compared to those in the EP. The overweight and obese adolescents were more likely to be dissatisfied compared to individuals with low and normal BMI (OR $4.10 ; p=0.003)$. The model according to the BSQ showed that female adolescents were more likely to be dissatisfied compared to males (OR 2.89; $p<0.001$ ). Regarding the period of adolescence, those in the MP and EP showed, respectively, 56\% (OR 0.65; $p=0.050)$ and $45 \%$ (OR 0.43 ; $p=0.000)$ less chance of feeling dissatisfied compared to adolescents in the LP. The overweight and obese, in turn, were more dissatisfied compared to adolescents with low and normal BMI (OR 3.66; $p<0.001)$.

\section{Discussion}

In the present study, the prevalence of dissatisfaction with body image was low among adolescents in small municipalities of Minas Gerais (BSQ) compared to other adolescents from other regions of $\mathrm{Brazil}^{(14-16)}$. However, the results showed some factors related to dissatisfaction, such as the early period of adolescence, sex, and overweight. Regarding the early period, this dissatisfaction might have manifested by the difficulty that teenagers have to create an identity with their body image, due to the morphological and biopsychosocial changes that happen during puberty ${ }^{(20)}$. In female adolescents, this effect may be even more intense, as they may feel more vulnerable to sociocultural pressures to achieve an ideal body shape, often difficult to obtain ${ }^{(21)}$. For Maloney $\mathrm{et} \mathrm{al}^{(22)}$, the teenager in the age range of 10 to 13 years may be more concerned with their image and body language, turning their attention to weight reduction. The adolescents seem to increase their personal expectations after menarche, being more dissatisfied with changes related to the accumulation of body fat ${ }^{(4,23)}$.

Regarding male adolescents, the majority wanted a greater silhouette than the actual figure. Interestingly, in this group the maturation process is characterized by decreased accumulation of body fat and increased fat-free mass ${ }^{(24)}$. Perhaps that is why this dissatisfaction tends to decline with advancing puberty ${ }^{(24,25)}$. While the standard for the female ideal body is thin, for boys the propagated model is a muscular and lean body ${ }^{(25,26)}$.

In this research, we observed that female adolescents had higher body dissatisfaction compared to their peers in the analysis of all instruments (BSQ, EEICA, and SSA). Moreover, they showed nearly twice the chance of presenting body dissatisfaction in relation to the opposite sex (SSA - OR 1.494; $p<0.001$ and BSQ - OR 2.893; $p<0.001)$. Jones et a ${ }^{(26)}$ warns that the female adolescent, even with an adequate weight or below the ideal, tends to feel fat or disproportionate, featuring a distorted perception of body image.

Overweight adolescents were more dissatisfied with their body image. According to the adjusted model, these students were four times more likely to present body image dissatisfaction (SSA - OR 4.108; $p<0.001$ and BSQ - OR $3.66 ; p<0.001)$ compared to their peers. This result is in line with previous studies and shows the seriousness of the situation, because these adolescents are at risk of diseases such as diabetes, hypercholesterolemia, among others, which can cause serious impairments in the emotional sphere, especially those related to their body acceptance ${ }^{(7,25)}$.

Studies such as those by Mattos and Luz ${ }^{(27)}$ discussed obesity in the prospect of human and social sciences, emphasizing the importance that the thin body has in society, as it seems to be the only type currently valued and recognized, causing suffering and illnesses in subjects that do not fit the body type without fat accumulation. According to these researchers, a worked out body seems to be more valued and recognized. This overvaluation of thinness transforms fat into a symbol of moral failure and the obese becomes increasingly stigmatized as an unwelcome being in society ${ }^{(27)}$.

Studies in Brazil showed that body satisfaction in adolescents and children ranges from a $64-82 \%{ }^{(28)}$. Conti et al ${ }^{(14)}$ found a mean of $73.2 \pm 36.4$ points on the BSQ in adolescents in the metropolitan region of São Paulo. Ours results with adolescents from small municipalities in the Zona da Mata Mineira presented a mean of $67.6 \pm 30.0$ points of BSQ. Del Duca $e t a^{(7)}$ evaluated 5,028 adolescents from public schools in the state of Santa Catarina and found that $52.9 \%$ selected an ideal silhouette different than that selected as real; among these $16.7 \%$ (95\% CI 15.7-17.7) were dissatisfied with their weight and would like to increase it, and $36.2 \%$ (95\% CI 34.9-37.5) would like to decrease it. Regarding the adolescents in the municipalities of Minas Gerais in this study, $78.9 \%$ were dissatisfied with their body image by SSA because they wanted a different silhouette than the real one. Of these, $60.8 \%$ wanted a smaller silhouette, which demonstrates the desire for a thinner body type also in adolescents from rural municipalities.

The results indicate that body dissatisfaction is a reality in the lives of adolescents, and the morphological changes occurring during adolescence, sex, and nutritional status 
are factors related to such negative feelings of body image. However, the study had some methodological limitations that should be considered, as, for instance, the cross-sectional design, which did not allow causal inferences to be made. Still, it was important to identify factors that may influence the dissatisfaction with body image of adolescents from small municipalities. Epidemiological and school-based studies are essential to provide information on the dynamics of the adolescent, assisting educators and health professionals with the issue.

It was found that the prevalence of dissatisfaction with body image was low in adolescents from small municipalities of Minas Gerais; however, the majority wanted a different

\section{References}

1. Papalia DE, Feldman RD. Desenvolvimento humano. $12^{\text {th }}$ ed. São Paulo: McGraw Hill/Artmed; 2013.

2. World Health Organization. Nutrition in adolescence: issues and challenges for the health sector: issues in adolescent health and development. Geneva: WHO; 2005.

3. WHO; UNICEF. Breastfeeding and maternal medication: recommendations for drugs in the 8th WHO Model List of Essential Drugs. Geneva: WHO; 1995.

4. McCabe MP, Ricciardelli LA. A longitudinal study of pubertal timing and extreme body change behaviors among adolescent boys and girls. Adolescence 2004;39:145-66.

5. Siervogel RM, Demerath EW, Schubert C, Remsberg KE, Chumlea WC, Sun S et al. Puberty and body composition. Horm Res 2003;60 (Suppl 1):36-45.

6. Santos EM, Tassitano RM, Nascimento WM, Petribú MM, Cabral PC. Body satisfaction and associated factors among high school students. Rev Paul Pediatr 2011;29:214-23.

7. Del Duca GF, Garcia LM, Sousa TF, Oliveira ES, Nahas MV. Body weight dissatisfaction and associated factors among adolescents. Rev Paul Pediatr 2010;28:340-6.

8. Alves E, Vasconcelos Fde A, Calvo MC, Neves Jd. Prevalence of symptoms of anorexia nervosa and dissatisfaction with body image among female adolescents in Florianópolis, Santa Catarina state, Brazil. Cad Saude Publica 2008;24:503-12.

9. Thompson JK. The (mis)measurement of body image: ten strategies to improve assessment for applied and research purposes. Body Image 2004;1:7-14.

10. Pelegrini A, Petroski EL. The association between body dissatisfaction and nutritional status in adolescents. Human Moviment 2010;11:51-7.

11. Pereira EF, Graup S, Lopes AS, Borgatto AF, Daronco LS. Body image perception in children and adolescents with different socio-economic status in the city of Florianópolis, in the state of Santa Catarina, Brazil. Rev Bras Saude Mater Infant 2009;9:253-62.

12. Brasil - Instituto de Pesquisa Econômica Aplicada. Série Caracterização e Tendências da Rede Urbana do Brasil. Brasília: IPEA; 2001.

13. Brasil - Instituto Brasileiro de Geografia e Estatística [homepage on the Internet]. Censo 2000 - cidades [cited 2009 May 5]. Available from: http:// www.ibge.com.br/cidadesat

14. Conti MA, Cordás TA, Latorre MR. A study of the validity and reliability of the Brazilian version of the Body Shape Questionnaire (BSQ) among adolescents. Rev Bras Saude Mater Infant 2009;9:331-8. silhouette. The results showed that students in early adolescence showed greater dissatisfaction in relation to other periods, as well as females and overweight adolescents. Studies such as the present one can provide information about the main factors associated with body dissatisfaction among adolescents, and avoid behaviors adopted as a result, which can be harmful to adolescents when they seek, at all costs, a physical appearance considered ideal.

\section{Acknowledgements}

We are thankful to all schools for the availability and for the encouragement of students to participate in this research.

15. Conti MA, Slater B, Latorre MR. Validity and reproducibility of Escala de Evaluación da Insatisfación Corporal para Adolescentes. Rev Saude Publica 2009;43:515-24.

16. Conti MA, Latorre MR. Study of validity and reliability of one contour rating scale to adolescence. Psicol Estud 2009;14:699-706.

17. Cordás TA, Castilho S. Body image on the eating disorders - evaluation instruments: "Body Shape Questionnaire". Psiquiatr Biol 1994;2:17-21.

18. Gordon CC, Chumlea WC, Roche AF. Stature, recumbent length, and weight. In: Lohman TG, Roche AF, Martorell R, editors. Anthropometric standardization reference manual. Champaing: Human Kinetics Books; 1988. p. 3-8.

19. De Onis M, Onyango AW, Borghi E, Siyam A, Nishida C, Siekmann J. Development of a WHO growth reference for school-aged children and adolescents. Bull World Health Organ 2007;85:660-7.

20. Smolak L. Body image in children and adolescents: where do we go from here? Body Image 2004;1:15-28.

21. Matias TS, Rolim MK, Kretzer FL, Schmoelz CP, Andrade A. Corporal satisfaction associated with physical activity practice during adolescence. Motriz 2010;16:370-8.

22. Maloney MJ, McGuire J, Daniels SR, Specker B. Dieting behavior and eating attitudes in children. Pediatrics 1989;84:482-9

23. Araújo CL, Dumith SC, Menezes AM, Hallal PC. Measured weight, selfperceived weight, and associated factors in adolescents. Rev Panam Salud Publica 2010;27:360-7.

24. Castro IR, Levy RB, Cardoso LO, Passos MD, Sardinha LM, Tavares LF et al Body image, nutritional status and practices for weight control among Brazilian adolescents. Cienc Saude Coletiva 2010;15 (Suppl 2):3099-4108.

25. Presnell K, Bearman SK, Stice E. Risk factors for body dissatisfaction in adolescent boys and girls: a prospective study. Int J Eat Disord 2004;36:389-401.

26. Jones DC, Vigfusdottir TH, Lee Y. Body image and the appearance culture among adolescent girls and boys: an examination of friend conversations, peer criticism, appearance magazines, and the internalization of appearance ideals. J Adolescent Res 2004;19:323-39.

27. Mattos RS, Luz MT. Surviving to the stigma of fat: a socio-anthropological study on obesity. Physis 2009;19:489-507.

28. Pelegrini A, Petroski The association between body dissatisfaction and nutritional status in adolescents EL. Hum Movt 2010;11:51-7. 